\title{
Sir Charles Lyell's travels in New Brunswick, Canada, in 1852
}

\author{
Randall F. Miller ${ }^{1 *}$ and Diane N. BuhaY ${ }^{2}$ \\ 1. Steinhammer Palaeontology Laboratory, Natural Science Department, New Brunswick Museum, \\ Saint John, New Brunswick E2K 1E5, Canada \\ 2. Ward Chipman Library, University of New Brunswick, Saint John, New Brunswick E2L 4L5, Canada \\ *Corresponding author $<$ randall.miller@nbm-mnb.ca $>$
}

Date received, 5 February 2007 g Date accepted 17 April 2007

\begin{abstract}
Geologist Sir Charles Lyell made a brief visit to New Brunswick, Canada, during his 1852 visit to North America. Lyell traveled to Albert Mines during the peak of the albertite controversy, visited the Reversing Falls and graphite mines in Saint John, and took a steamboat trip up the Saint John River to Fredericton where he visited his friend, Lieutenant Governor Sir Edmund Head. Lyell's friendship with Head likely had a long-term effect on the development of geological sciences in New Brunswick and Canada. New Brunswick newspapers followed Charles Lyell's travels through the province and expressed hope that Lyell's observations on the geology of New Brunswick would cast a favourable opinion on the province's geological wealth and foster economic development.
\end{abstract}

RÉSUMÉ

Le géologue Sir Charles Lyell a effectué un bref arrêt au Nouveau-Brunswick, Canada, au cours de sa visite de 1852 en Amérique du Nord. Lyell s'est rendu à Albert Mines au moment culminant de la controverse au sujet de l'albertite; il a visité les chutes réversibles et les mines de graphite de Saint-Jean; et il a remonté en vapeur le fleuve Saint-Jean jusqu'à Fredericton, où il a rendu visite à son ami, le lieutenant-gouverneur Sir Edmund Head. L'amitié de Lyell et Head a probablement eu un effet de longue durée sur l'essor des sciences de la terre au Nouveau-Brunswick et au Canada. Les journaux du Nouveau-Brunswick ont suivi les déplacements de Charles Lyell à l'intérieur de la province; ils ont exprimé l'espoir que les observations de Lyell sur la géologie du Nouveau-Brunswick engendreraient une opinion favorable sur la richesse géologique de la province et qu'elles favoriseraient le développement économique.

[Traduit par la redaction]

\section{INTRODUCTION}

Sir Charles Lyell (1797-1875) (Fig. 1) toured and lectured widely in eastern North America (Dott 1996, 1998; Wilson 1998) during his four trips to the continent in 1841-42, 1845, 1852, and a brief return to the New York Industrial Fair in 1853. His first three trips included stops in the eastern provinces of British North America where most of his time was spent in Nova Scotia. Although his 1845 trip involved only a short stop in Halifax en route to Boston, Lyell spent significant time in the field in Nova Scotia during both his 1841-42 and 1852 trips. In 1841 Lyell arrived in Halifax on 31 July 1841 and sailed directly to Boston on 2 August 1841 . On his return trip to Britain he sailed from Boston (Lyell 1845) and stopped in Halifax on 16 July 1842 . He then spent a month studying the geology of Nova Scotia (Lyell 1845; Dott 1996; Calder 2006). Lyell visited Joggins, where he was guided by Abraham Gesner
(1797-1864). He also traveled to Pictou where he met John William Dawson (1820-1899) in the field. Lyell departed Halifax for England on 18 August 1842 (Dott, 1996).

Lyell's better known trip to Nova Scotia was in 1852. It was during this visit that Lyell went to Joggins with Dawson and discovered tetrapod fossils in tree trunks (Lyell 1881; Wilson 1998; Calder 1998). During this trip, Lyell arrived in Halifax on 31 August 1852 and spent a few very productive days with Dawson in the field. He then traveled through New Brunswick, eventually arriving in Boston by 17 September 1852 to visit friends, and delivering the last of his Lowell Lectures (Dott 1996, 1998; Wilson 1998). Lyell left for England from the United States about 29 November 1852.

Although Lyell's activities in Nova Scotia are well known, especially in connection with his second trip to Joggins in 1852, there is very little record of his travels through New Brunswick (Wilson 1998) and the geological observations he made there. 




Fig. 1 Sir Charles Lyell.

In this paper we use letters and newspaper accounts to reconstruct the approximately ten days that Sir Charles Lyell spent in New Brunswick. There are some conflicting dates in the accounts (Lyell 1881; Wilson 1998) and we present the best timeline we can reconstruct from various sources (Fig. 2).

\section{LYELL'S TRAVELS IN NEW BRUNSWICK}

Sir Charles Lyell arrived in Halifax on 31 August 1852 on his third trip to North America (Dott 1996). His arrival was noted in New Brunswick newspapers: these included the Weekly Observer (7 September 1852), which reported "Sir Charles Lyell, who honorably stands at the very head of modern Geologists, accompanied by Lady Lyell, also came out in the last steamer to Halifax, Lady Lyell arrived in this city on Friday in the company with Sir Edmund and Lady Head, and proceeded with them to Fredericton." The same paper had noted just above in the same column that "Sir E Head, Lady Head \& family returned from 3 months in England by the last steamer to Halifax" (Weekly Observer, 7 September 1852). Sir Edmund Head was the Lieutenant-Governor of New Brunswick and a friend of Sir Charles. Lady Lyell, who accompanied Sir Charles Lyell on his travels, went on to Fredericton while Lyell made his field work plans. Sir Edmund and his family, accompanied by Lady Lyell made their way to Saint John; they progressed by land to Windsor, Nova Scotia, then on the steamer Commodore to Saint John (The Standard, St. Andrews, 15 September 1852), where they took the 9 o'clock steamer Anna Augusta up the Saint John River to Fredericton (New Brunswick Courier 4 September 1852).

Lyell's work at Joggins that year is well known (Calder 2006) owing to the famous discovery of fossil tetrapods inside the remains of standing trees. Wilson (1998) indicates that Lyell and Dawson arrived in Amherst on 3 September 1852 and spent five days at Joggins. This conflicts with Lyell's record of his travels in a letter written to his father-in-law, Leonard Horner. In the letter dated 12 September 1852 from Government House, Fredericton (Lyell 1881, p. 179), Lyell described how on 2 September 1852 he crossed between Truro and Amherst. The two then traveling on to Joggins where Lyell and Dawson made their discovery (Calder 2006). Using the 2 September date from the letter, Lyell could have arrived in Joggins that same day and spent five days in the field from 2 to 6 September. When they finished at Joggins, Lyell left for New Brunswick and could have arrived at his destination that same day. The Morning News (6 September 1852) in Saint John reported "Sir Charles Lyell is now in Albert County en route for St. John. The object of his visit, we understand, is to examine the geological features of that fine County; and he will no doubt pronounce an opinion upon what he sees." He must have made public his plans to examine the Albert Mines area since another newspaper made mention of his intentions: "Sir Charles is traveling by the land route from Halifax, with the object it is stated of visiting the rich and extensive Mines in Albert County, and his opinion as to their character and importance will be looked for with much interest" (Weekly Observer, 7 September 1852).

The letter to Leonard Horner describes the next steps of this journey, which he undertook with Dawson:

"After Joggins we returned to Amherst and thence to Dorchester, where a friend of Head's, called by some his prime minister, $\mathrm{Mr}$ Chandler, received us in a handsome house, and his son took us next day to see a wonderful bed or vein of ashphaltum, the subject of a hotly contested lawsuit - a vein from one to eleven feet thick, of pure pitch coal, or something like it, traversing fractured coal measures. It is too puzzling to attempt an account of it. As Gesner has consulted me, and the other party Dawson, we are trying to persuade them to compromise the suit. About 3,0001. pocketed already by the lawyers! The chief point being, whether it be a bed of coal which passes by a crown lease, or of ashphalte or some mineral which would not pass." (Lyell 1881, p. 182)

The house where Lyell stayed in Dorchester belonged to Edward Barron Chandler, a future Father of Confederation (Swift 1972). The elegant house, called Rocklyn (Fig. 3), was the centre of local Society, where lawyers and government officials were often entertained; it remains an important historic home 


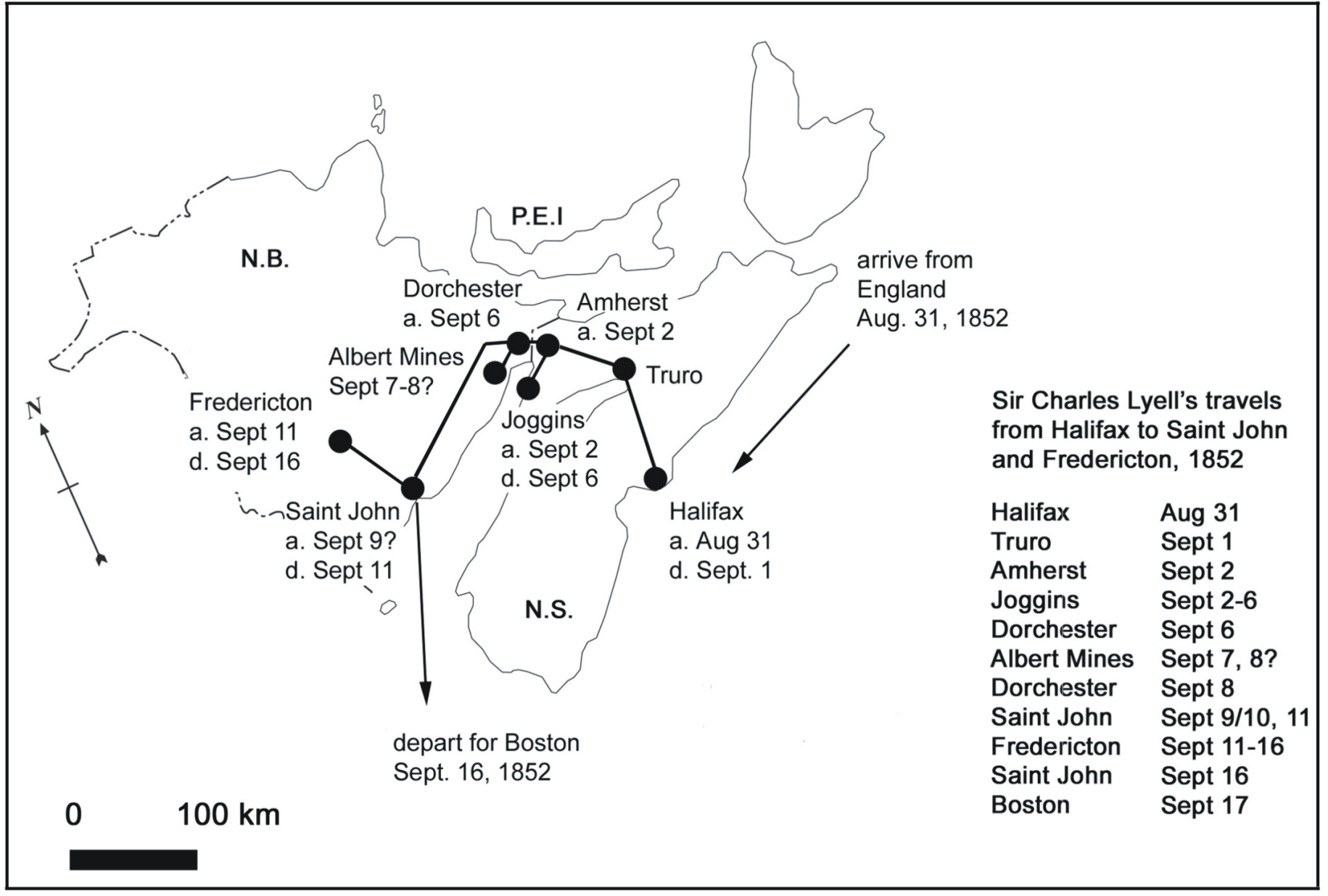

Fig. 2 Sir Charles Lyell's travels and timeline through Nova Scotia and New Brunswick, Canada in 1852: “a." indicates date of arrival; "d." indicates date of departure. N.B. = New Brunswick, N.S. = Nova Scotia and P.E.I. = Prince Edward Island.

Fig. 3 Rocklyn (later known as Chandler House), home of Edward Chandler in Dorchester, New Brunswick, about 1910. Courtesy of New Brunswick Museum Archives, X13823.

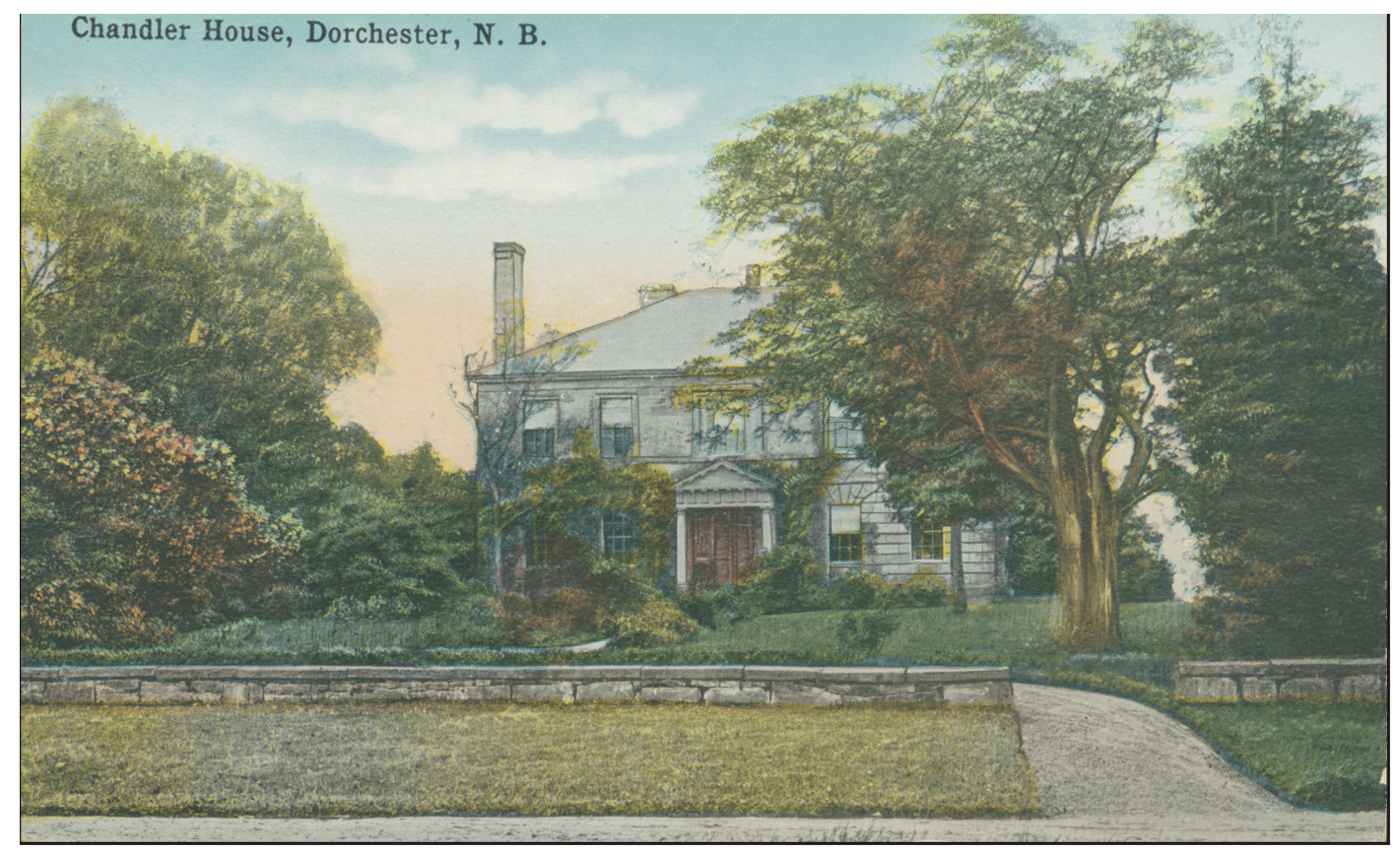


in New Brunswick. Edward Chandler became a leading public figure in New Brunswick: a lawyer, a Member of the Legislative Assembly Executive Council, Railway Commissioner and eventually Lieutenant-Governor of New Brunswick in 1878.

Lyell and Dawson likely crossed the Memramcook and Peticodiac rivers to make the short trip to Albert Mines (Fig. 4a) to see the substance later called albertite, which had become the centre of a hotly contested lawsuit as Lyell wrote. Dawson $(1853,1855)$ later noted the palaeoniscid fish found at Albert Mines (Jackson 1851), as well as general geological observations made during the trip. Lyell was well aware of current events, for the law case he referred to was that pitting Abraham Gesner against William Cairns: it had only just come to a conclusion the previous month in Albert County court (Anonymous 1853). Albertite (Fig. 4b), and the right to mine it as Lyell noted, was at the heart of the case and Lyell apparently wanted to see it for himself.

Albertite is a bitumen claimed to have been discovered near Albert Mines by Gesner and also by a competitor Robert Foulis (Wright and Miller 1990; Haigh 2000; Brice 2002; Martin 2003). Gesner took little notice of it until he developed his process for the distillation of kerosene. By the time Gesner realized the importance of the albertite deposit, he discovered another party had purchased the mining rights to minerals and coal on the land, and had sold the rights to Gesner's competitors. Gesner then secured ownership of the land, but was unable to prevent his competitors from mining it. The resulting court case dealt with two issues. One involved the question of mineral rights and access on private land, and the other concerned whether albertite was a type of coal. Gesner's lawyer argued that the mining license only included coal and a limited list of minerals, and not albertite (Martin 2003). Experts had been lined up by the lawyers for the plaintiff, including Professor Benjamin Silliman and Dr. Charles Jackson, and for the defendant Dr. James Robb and Dr. Joseph Leidy. Lyell indicated in the letter to Horner that Gesner asked for his opinion concerning albertite (Lyell 1881). Lyell notes also that Dawson had been asked for his opinion by the opposing side. Gesner and Lyell were acquainted from Lyell's first North American visit (Lyell 1845), although they were not necessarily on friendly terms as they had previously had a disagreement concerning Gesner's interpretation of Carboniferous strata in Nova Scotia (Calder 2006).

Lyell commented in the letter to his father-in-law about albertite that "It is too puzzling to attempt an account of it." (Lyell 1881, p. 182). Albertite is, as Gesner argued, a bitumen and not coal. The jury in the court case however had been asked by the judge to render an opinion on the matter and, after thirteen weeks of testimony by various experts, the jury determined they believed the material to be coal (Anonymous 1853). Lyell's assessment that it was "too puzzling" was probably a disappointment to Gesner. The Morning News (20 September 1852) reported:

"Sir Charles Lyell's Opinion of New Brunswick. This eminent geologist, now in New Brunswick, has visited some of the districts of Westmorland, and other parts of the Province - and we are gratified to learn that he expresses a highly favourable opinion of the geological features of this country, so far as his observations have extended. We understand that he is unable to decide the question for the Lawyers, as to whether the substance found in Albert, in such abundance, comes under the cognomen of Coal, or Ashphaltum, as its character differs from both. It being a new thing to science, Sir Charles is puzzled to know, on first examination, what to call it."

The court case had ended 3 August 1852, more than a month before Lyell's visit. However if the newspaper was correct then Lyell's opinion may still have carried great weight as the paper noted he was unable to decide the question for the lawyers. If Lyell had determined the correct nature of the material would they have revisited the question?

In the letter to his father-in-law it sounds as though

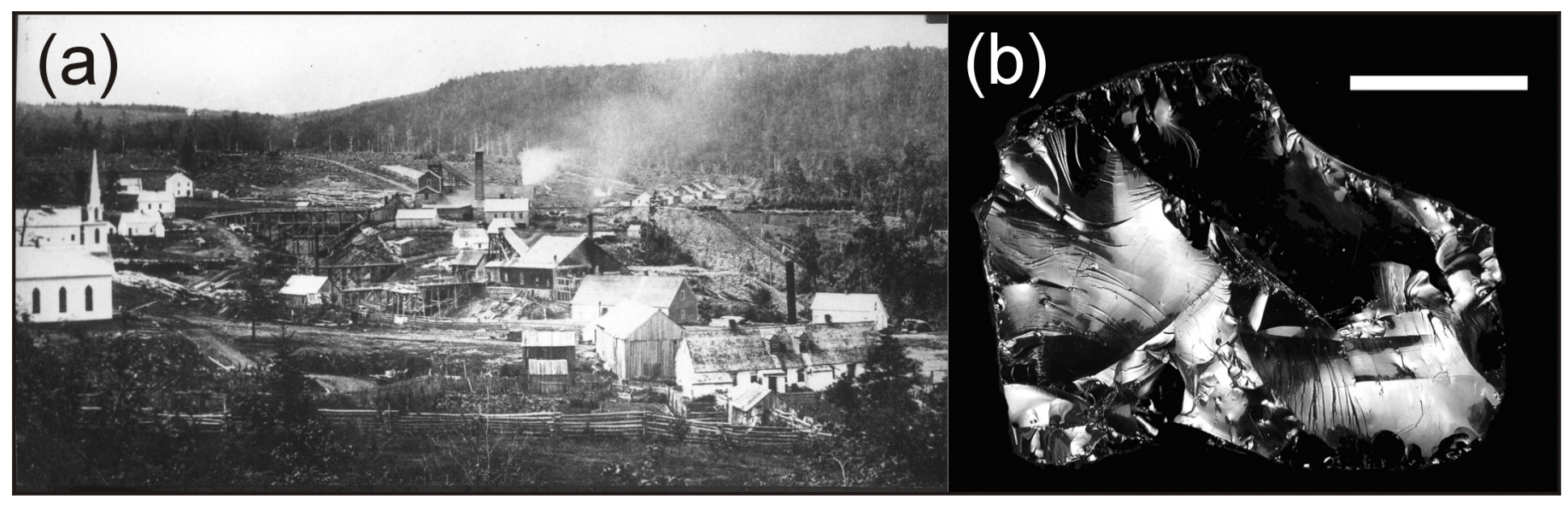

Fig. 4 a. Albertite mining site, Albert Mines, New Brunswick, 1860. Courtesy of Provincial Archives of New Brunswick, PANB Miscellaneous Collection - P1-21. b. Albertite. Courtesy of New Brunswick Museum Collection, NBME 1133. Scale bar, $5 \mathrm{~cm}$. 
Dawson stayed with Lyell at Chandler's home in Dorchester (Lyell 1881) and they visited the vein of ashphaltum together (Dawson 1855). Following his visit to Albert Mines, Lyell must have returned to Dorchester. Moving on with his travels Lyell wrote, "After Dawson left me at Dorchester, I traveled about 150 miles at one stretch in a stage coach towards St. John's, New Brunswick. Chandler and two friends, good company inside" (Lyell 1881, p. 182). The New Brunswick Courier (11 September 1852) reported that "Sir Charles Lyell arrived in town [Saint John] yesterday, from Albert County. His Excellency Sir Edmund Head came down the day before, to await his arrival, and we believe they proceeded to Fredericton to-day." The Weekly Chronicle (10 September 1852) reported that Sir Edmund "arrived in town [Saint John] last evening [Sept. 9], and took lodgings at the Waverly. There was a meeting of the Executive Council this morning at 10 o'clock. Sir Edmund returns to the seat of Government [Fredericton] to-morrow morning." Sir Charles' stage coach traveling companion, Edward Chandler, was a member of Executive Council and probably attended the 10 September 1852 meeting with Sir Edmund. These two newspaper accounts suggest Lyell and Chandler probably arrived in Saint John late on 9 September after a long coach ride. Lyell would then have spent two nights in Saint John, probably with Sir Edmund at Waverly House (Fig. 5). Both accounts agree that Lyell and Head left for Fredericton on 11 September.

Acheson (1985, p. 169) wrote that Sir Charles Lyell had been a lecturer at the Mechanics' Institute in Saint John. If he did speak to the Mechanics' Institute it would likely have been the evening of Friday 10 September 1852, although the Annual Report (New Brunswick Courier, 4 June 1853) for the institute does not list Lyell amongst the lecturers for 1852, and none of the newspapers mention a lecture. Lyell probably passed through Saint John briefly again after leaving Fredericton by steamer 16 September 1852 (Wilson 1998), arriving in Boston the next day, likely on a ship out of Saint John. In a biography of Sir Edmund Head, Gibson (1976, pp. 381-386) credited Head with bringing "an old friend, the geologist Sir Charles Lyell, and Professor James Finlay Weir Johnston of Durham, an agricultural scientist, to the province to give public lectures." Professor Johnston (Wynn 1985, pp. 435-436) published an influential "Report on the agricultural capabilities of the Province of New Brunswick" (Johnston 1850) and lectured to the Saint John Mechanics' Institute on 21 December 1849 on that same topic.

Lyell and Head made a brief geological excursion in Saint John to the Reversing Falls, probably on 10 or 11 September 1852. At the Falls (Fig. 6) the contact of the Neoproterozoic Brookville terrane and the Cambrian Avalon terrane is exposed in dramatic cliffs where the St. John River empties into the Bay of Fundy. The six metre tidal range in the bay at Saint John causes the river to run backwards with the rising tide producing impressive standing waves in the gorge (Flaherty 1989). Lyell wrote, "Sir E. Head met me at St. John, and we examined the Falls together. It is very strange to see a great river or tidal current, rush first in for several hours, then out of a narrow gorge formed of metamorphic rocks, vertical beds of limestone and slate, invaded by trap and syenite. They ought to be called the Rapids rather. The vessels, a little fleet laden with timber, wait till the tide flows neither way, and then sail in or out. The whole harbour is beautiful” (Lyell 1881, p. 182-183). Lyell and Head also examined graphite mines which had opened at the Reversing Falls in 1850 (Martin 2003). Newspapers during Lyell's visit advertised "New Brunswick Pure Black Lead" from the Saint John Mining Company. Loring Bailey (1864, p. 64) recorded their operation in his report on mines and minerals in New Brunswick. He noted that in 1853, a total of 89936 pounds were exported, but that by 1864 work at the mines had been discontinued. The first mines were located near the narrowest part of the gorge just below the suspension bridge (Fig. 6). The Morning News (20 September 1852) wrote "When in St. John he [Lyell] visited the black lead, or plumbago mines, at the Falls, and remarked that Anthracite Coal would yet be found in that vicinity, in immense beds, as this plumbago was but the outer corruscation of the treasure within. We hope the Company will keep on digging until they strike a vein, and their fortunes are made." The graphite was being mined from veins in the Neoproterozoic marble of the Green Head Group. Lyell's prediction of anthracite coal from the area never materialized.

On 11 September 1852 Lyell and Head boarded a steamer bound for Fredericton (Fig. 7), probably at Indiantown in the city's north end. Lyell reported that "The sail up the river eighty or ninety miles from St. John to Fredericton is fine - picturesque, till a country of nearly horizontal coal measures produces tame outlines and low hills.... Our stay at Government House was very agreeable,...”(Lyell 1881, p. 183). Steamer travel along the river was the main means of transport through most of the 1800's and numerous boats made regular trips (MacBeath and Taylor 1982). The fastest among them could make the trip in about six hours. Lady Lyell was already at Government House in Fredericton (Fig. 8) and both Sir Charles and Lady Lyell spent a few days there before leaving for Boston on 16 September 1852 (Wilson 1998).

\section{LYELL'S GEOLOGICAL OBSERVATIONS IN NEW BRUNSWICK}

During his brief trip through New Brunswick, Lyell said little about the geology, but his presence and pronouncements may have had a subtle and lasting influence. In Albert County his puzzlement over the nature of the material we now know as albertite failed to produce a resolution that seemed to be expected in advance of his visit. However, based on observations made during the trip with Lyell, Dawson (1853) described the geology in great detail for the Geological Society of London, and also discussed the geology of the region in Acadian Geology (Dawson 1855). In Saint John, Lyell's comments concerning an abundance of anthracite coal at the Reversing Falls prompted the local newspaper to encourage the mining company to keep digging even though they would never have struck traditional 


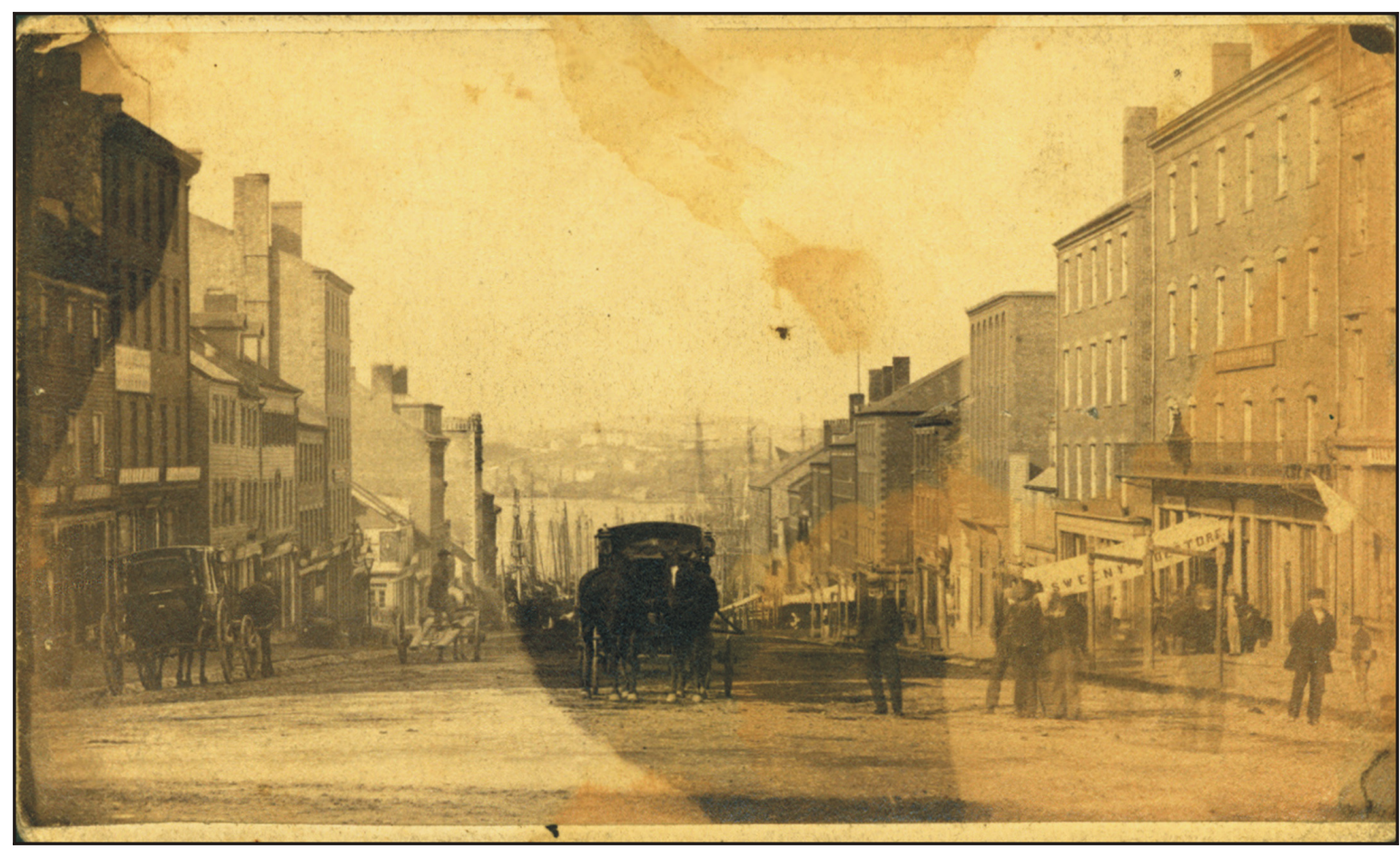

Fig. 5 Waverly House (far right), looking west down King Street, Saint John, New Brunswick, about 1870. Courtesy of New Brunswick Museum Archives, 1989.31.1.



Fig. 6 Reversing Falls, Saint John, New Brunswick, about 1910. Courtesy of New Brunswick Museum Archives, 1987.17.1392. The first graphite mines were located near the river edge between the bridges. The road bridge was opened 1 January 1853. 


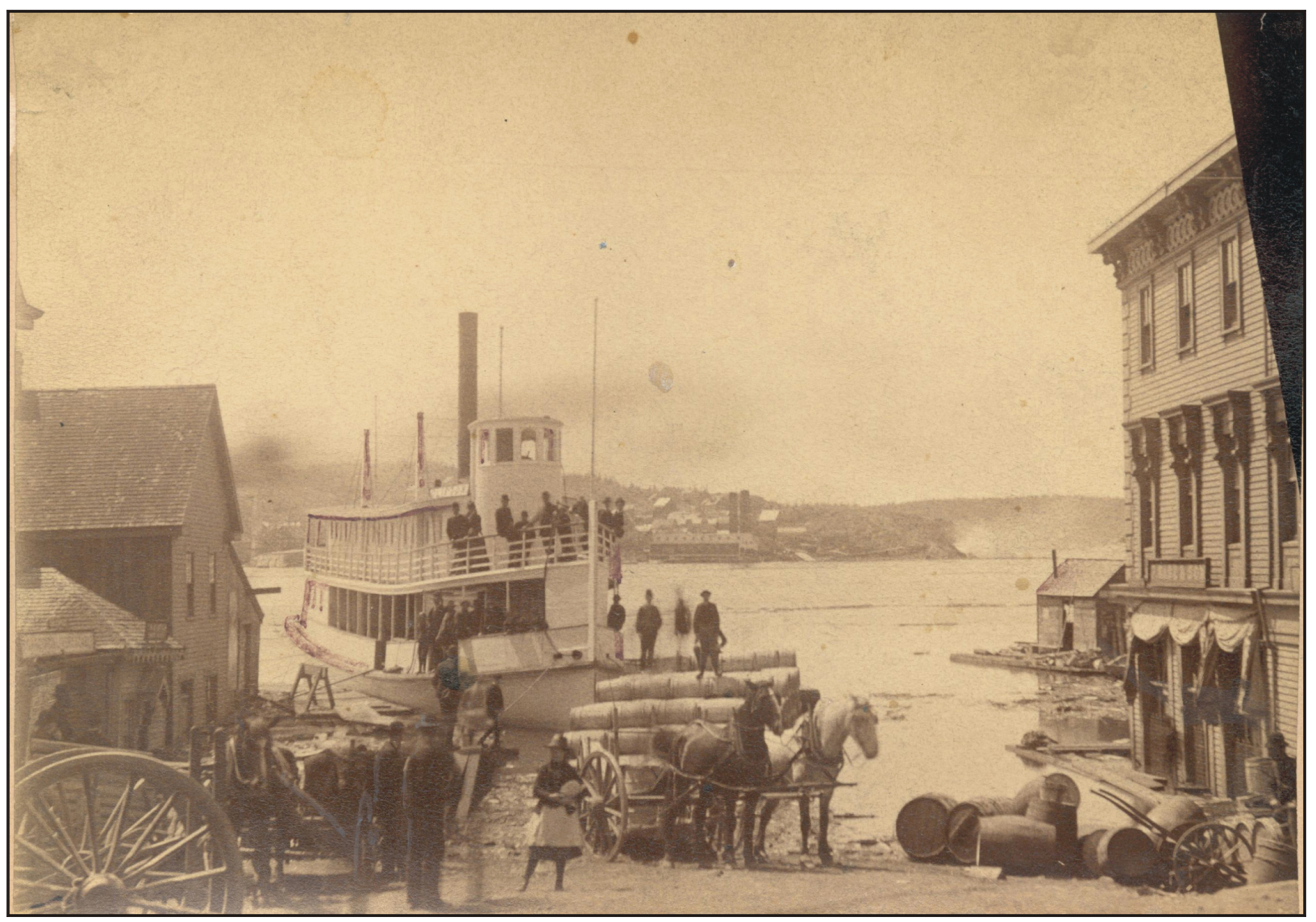

Fig. 7 The steamer, Clifton, at Indiantown, Saint John, New Brunswick, during a Freshet, 1887. Courtesy of New Brunswick Museum Archives, 1964.147U. River travel by steamer was a common mode of travel between Saint John and Frederiction during most of the 1800s.

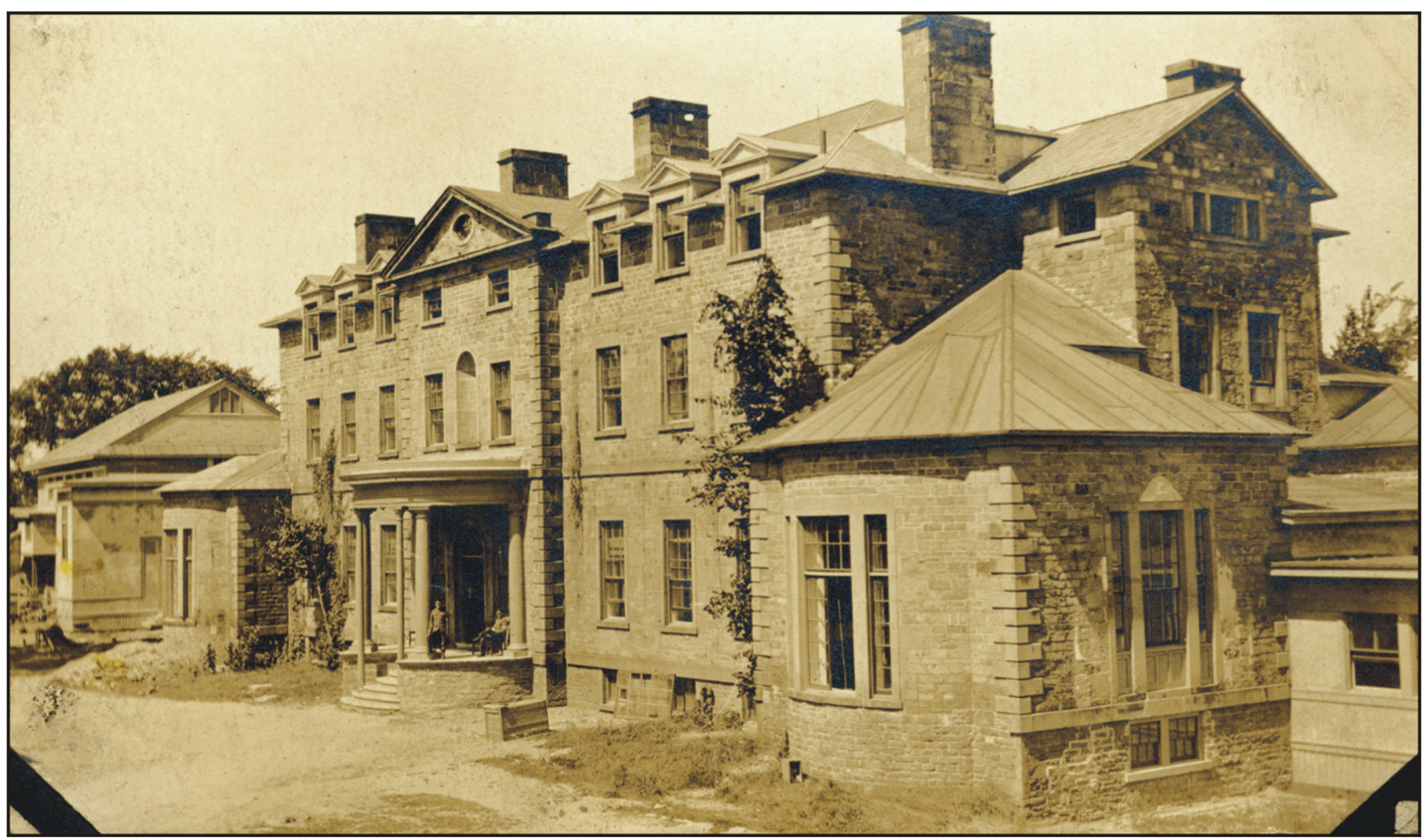

Fig. 8 Fredericton, New Brunswick, Old Government House, about 1917. Courtesy of New Brunswick Museum Archives, 1990.11.2. 
coal beds. The graphite beds were mined in the Precambrian marble for many years but were eventually abandoned.

Not much has been recorded about Lyell's time in Fredericton (Wilson 1998); however his visit may have had a lasting effect on the development of geological sciences in New Brunswick. When Lyell was in Fredericton, James Robb was the professor of chemistry and natural sciences at Kings College (Bailey 1976). Robb and Head were well acquainted, in fact Head had personally paid for a series of lectures Robb delivered about Agricultural Chemistry in 1850 (Jarrell 1973). Unfortunately Bailey (1983) reported that no Robb letters exist for the period of Lyell's visit. Sir Edmund Head was influential in changing the direction of education at Kings College and the subsequent establishment of the University of New Brunswick (Kerr 1954; Jarrell 1973; Findlay 1991). Lyell and Head must have discussed the matter since Lyell wrote to Leonard Horner (Lyell 1881; Wilson 1998) about the state of education in New Brunswick and about Head's efforts to change it. Head and others believed an education in New Brunswick required more than classics, and that courses in science and engineering were needed. Only a month after Lyell's visit, Head moved the college council to agree to devote more attention to the teaching of civil engineering. In 1861 Loring Bailey succeeded James Robb as professor of chemistry and natural sciences and greatly improved the status of geology at the university.

The friendship of Lyell and Head, and perhaps their time in New Brunswick, had another lasting effect on the development of geological sciences in Canada. In 1855, J.W. Dawson was appointed principal of McGill College in Montreal following his unsuccessful bid to win the Edinburgh Natural History Chair (Sheets-Pyenson 1992). Sir Edmund Head, by then the Governor General, recommended Dawson to the board of governors of McGill. Head had first met Dawson in 1852 through his friend Charles Lyell when they were introduced in Halifax prior to Lyell and Dawson traveling to Joggins (Eakins and Eakins 1990; Wilson 1998). Head was apparently so impressed with Dawson that he was later invited to join a commission of inquiry into the state of King's College, Fredericton. While in Fredericton, Head may also have had the opportunity to see the fossil amphibian discovery Lyell and Dawson had just made at Joggins. Lyell had the fossils with him to show to colleagues at Harvard University. Lyell began the letter to his father-inlaw on 12 September 1852 while still at Government House in Fredericton. By the time he sent the letter, Lyell was in Boston where he described spending a long day with Dr. Wyman, Professor of Anatomy at Harvard University, examining the Joggins fossils (Lyell 1881).

More generally there seemed to be high hopes that the comments of such an eminent scientist as Sir Charles Lyell would be of benefit to the province. The Standard, St. Andrews (15 September 1852) wrote "Sir Charles Lyell, the distinguished Geologist, who came out in the steamer for the purpose of visiting the Mining districts of this Province, proceeded round by land, in order to ascertain the nature of the soil and geologi- cal formations in the Eastern part of New Brunswick." Again, the Morning News (20 September 1852) summarized the visit by writing:

\begin{abstract}
"In the opinion of Sir Charles Lyell, this Province abounds in mineral wealth - such as coal, iron, copper \&c. \&c. - which will one day be explored and developed to the enrichment of the inhabitants. It requires but enterprise and capital to bring about these ends. Opinions from such a quarter cannot be over estimated. If Professor Johnson was capable of giving our Agricultural capabilities a good character, Professor Lyell will assist us in the mineral kingdom. We hope yet to hear from him, under his own hand. No doubt he will write a treatise upon what he has seen and approved of, in this Province. That alone will do us an immensity of good. We are informed that Sir Charles Lyell and our Lieut. Governor were school mates.... We hope when he returns to England he will give New Brunswick as good a name as he may think it deserves.”
\end{abstract}

In contrast to his first two North American visits, Lyell (1845) did not write an account of travels for his third trip. Dott $(1996,1998)$ wrote detailed descriptions of Lyell's lectures and travels in North America with no reference to his days in New Brunswick, and Wilson (1998) only briefly touched on those few days. Whatever hopes there seemed to be from Sir Charles Lyell's visit, there was little written by Lyell about his time in New Brunswick. Unlike Johnston (1850) whose report detailed the agricultural capabilities of the province, Lyell never produced a similar report, which seemed to be looked for by writers for the newspapers. Lyell's travels through New Brunswick were brief, not seemingly intended as an exploration of the province's geology. If not for his friendship with Sir Edmund Head, and perhaps a request from Abraham Gesner to comment upon the question of albertite, Sir Charles Lyell might not have visited New Brunswick at all.

\section{ACKNOWLEDGEMENTS}

The authors thank J. Bishop, C. Little and J. Longon, New Brunswick Museum Archives and Research Library; E. Costello and K. Hughes, Saint John Free Public Library; and P. Johnson Archives \& Special Collections, Harriet Irving Library, University of New Brunswick for their assistance. The New Brunswick Museum and the Provincial Archives of New Brunswick provided historical photographs. Helpful reviews and suggestions were provided by $\mathrm{H}$. Falcon-Lang and $\mathrm{M}$. Rygel. Comments from journal editor R. Fensome were appreciated. RFM gratefully acknowledges receipt of a Social Sciences and Humanities Research Council - Community University Research Alliances grant (833-2003-1015) and the support of the New Brunswick Environmental Trust Fund to study New Brunswick's geoscience heritage. 


\section{REFERENCES}

Acheson, T.W. 1985. Saint John. The making of a colonial urban community. University of Toronto Press, $314 \mathrm{p}$.

Anonymous. 1853. Report of a case tried at Albert Circuit, 1852 before his Honor Judge Wilmot and a special jury. Abraham Gesner vs William Cairns. W.L. Avery, Saint John, New Brunswick, 168 p.

BAILEY, A.G. 1976. Robb, James. In Dictionary of Canadian biography, volume 9, 1861 to 1870 . Edited by G.W. Brown, D.M. Hayne and F.G. Halpenny. University of Toronto Press, pp. 665-667.

Bailey, A.G. 1983. The letters of James and Ellen Robb: portrait of a Fredericton family in early Victorian times. Acadiensis Press, Fredericton, 173 p.

BAILEY, L.W. 1864. Report on the mines and minerals of New Brunswick, with an account of the present mining operations in the province. Queen's Printer, Fredericton, New Brunswick, 73 p.

BRICE, W.R. 2002. Abraham Gesner (1797-1864) - A petroleum pioneer. Oil-Industry History, 3, pp. 72-80.

Calder, J.H. 1998. The Carboniferous evolution of Nova Scotia. In Lyell: the past is the key to the present. Edited by D.J. Blundell and A.C. Scott. Geological Society of London, Special Publications, 143, pp. 261-302.

CAlder, J.H. 2006. "Coal Age Galapagos": Joggins and the lions of Nineteenth Century geology. Atlantic Geology, 42, pp. 37-51.

Dawson, J.W. 1853. On the Albert Mine, Hillsborough, New Brunswick. Geological Society of London, Quarterly Journal, 9, pp. 107-115.

DAwson, J.W. 1855. Acadian geology: an account of the geological structure and mineral resources of Nova Scotia and portions of the neighbouring provinces of British America. Oliver and Boyd, Edinburgh, Scotland, 388 p.

Dотт, R.H.JR. 1996. Lyell in America - his lectures, field work, and mutual influences, 1841-1853. Earth Sciences History, 15, pp. 101-140.

Dotт, R.H. JR. 1998. Charles Lyell's debt to North America: his lectures and travels from 1841 to 1853. In Lyell: the past is the key to the present. Edited by D.J. Blundell and A.C. Scott. Geological Society of London, Special Publications, 143, pp. 53-69.

Eakins, P.R., ANd Eakins, J.S. 1990. Dawson, Sir John William. In Dictionary of Canadian biography, volume 12, 1891 to 1900. Edited by F.G. Halpenny. University of Toronto Press, pp. 230-237.

FINDLAY, R.D. 1991. The origins of chemical engineering education in Canada. In Chemical engineering in Canada: an historical perspective. Edited by L.W. Shemilt. Canadian Society for Chemical Engineering, 25th Anniversary, Ottawa, pp. 3-10.
Flaherty, G.F. 1989. The Reversing Falls: the present outlet of the Saint John River in southern New Brunswick. Minerals and Energy Division, Department of Natural Resources and Energy, $19 \mathrm{p}$.

Gibson, J.A. 1976. Head, Sir Edmund Walker. In Dictionary of Canadian biography, volume 9, 1861 to 1870 . Edited by G.W. Brown, D.M. Hayne and F.G. Halpenny. University of Toronto Press, pp. 381-386.

Haigh, E. 2000. Bright lights and skullduggery. The Beaver, August / September 2000, pp. 32-37.

Jackson, C.T. 1851. Discovery of fossil fish in the coal formation of New Brunswick. American Journal of Science, 12, pp. 281-282.

JARRELL, R.A. 1973. Science education at the University of New Brunswick in the Nineteenth Century. Acadiensis, 2, pp. 55-79.

Johnston, J.F.W. 1850. Report on the agricultural capabilities of the province of New Brunswick. Fredericton, New Brunswick, 262 p.

KerR, D.G.G. 1954. Sir Edmund Head: a scholarly governor. University of Toronto Press, $259 \mathrm{p}$.

LyELL, C. 1845. Travels in North America; with geological observations on the United States, Canada and Nova Scotia, volume 2. John Murray, London, $272 \mathrm{p}$.

LYELL, K.M. 1881. Life, letters and journals of Sir Charles Lyell, Bart. Volume 2. AMS Press 1983 reprint, New York, 489 p.

MacBeath, G.B., AND Taylor, D.F. 1982. Steamboat days: an illustrated history of the steamboat era on the St. John River, 1816-1946. Print'N Press, St. Stephen, New Brunswick, $176 \mathrm{p}$.

Martin, G.L. 2003. Gesner's dream: the trials and triumphs of early mining in New Brunswick. Canadian Institute of Mining, Metallurgy and Petroleum - New Brunswick Branch, Fredericton, New Brunswick, $328 \mathrm{p}$.

SheEts-Pyenson, S. 1992. Horse race: John William Dawson, Charles Lyell, and the competition over the Edinburgh natural history chair in 1854-1855. Annals of Science, 49, pp. 461-477.

SwIFT, M. 1972. Chandler, Edward Barron. In Dictionary of Canadian biography, volume 10, 1871-1880. Edited by G.W. Brown, D.M. Hayne and F.G. Halpenny. University of Toronto Press, pp. 157-161.

Wilson, L.G. 1998. Lyell in America. Transatlantic Geology, 1841-1853. The Johns Hopkins University Press, 429 p.

Wright, H.E., AND Miller, R.F. 1990. Robert Foulis (17961866): New Brunswick inventor, entrepreneur and geologist. Geoscience Canada 17, pp. 101-104.

Wynn, G. 1985. Johnston, James Finlay Weir. In Dictionary of Canadian biography, volume 8,1851 to 1860 . Edited by F.G. Halpenny. University of Toronto Press, pp. 435-436.

Editorial responsibility: Robert A. Fensome 